\title{
BILl C-45 AND the Canadian PeTroleum Industry
}

\author{
NORM KEITH` AND JAMES FERGUSON"*
}

This article examines Bill C-\$S and its possible impact on the Canadian Petroleum Industry. Bill C. 45, An Act to amend the Criminal Code, establishes a new occupational health and safety (OHS) duty in the Criminal Code. If the duty is breached. eilher by individuals or organizations, it may result in a criminal charge of occupational heallh and safety criminal negligence.

Bill C-45 also changes the means by which organizations, including corporations, are held liable for offences under the Criminal Code. The "identificalton theory" of corporate criminal liability has now been replaced by no provisions in the Criminal Code to address the criminal liability of organizations. The first provision, which deals with offences such as the new OHS criminal negligence offence, requires proof of negligence. The second deals with a more classic objective fault element or mens rea.

The Canadian petroleum industry. especially in Alberia, has ofien relied upon outsourcing. contract provisions and structuring of relationships to minimize OHS legal liablity under applicable OHS statutes. However, there is no legal basis to contract out of the Criminal Code. It is more important than ever to emphasize proper contract language, indemnity provisions and OHS management systems.
Cel article porte sur le projet de loi C.45 et ses incidences éventuelles sur le secteur pétrolier canadien. Le projet de loi C.45, Loi modifiant le Code criminel, etablit une nouvelle obligation des services d'hygiène du travail (SHT) dans le Code criminel. Une infraction de l'obligation, par une personne ou un organisme. peut entrainer des accusations au penal pour negligence criminelle des services d'hygiène du travail.

Le projet de loi C-45 modifie aussi les moyens par lesquels les organismes, incluant les personnes morales. pewvent etre tenues responsables d'infractions dil Code criminel. La athéorie didentificalion" de la responsabilité criminelle de personnes morales a été remplacée par deux dispositions dans le Code criminel portant sur la responsabilité criminelle de personnes morales. La première disposition quitraite d'infractions comme la nouvelle infraction criminelle des services d'hygiene du travail exige une preuve de négligence. La deuxième porte sur unélément de faute plus classique. notamment le mens rea (intention coupable).

Le sectewr peirolier canadien, surtout en Alberta, a souvent fait appel à l'impartition, d̀ des dispositions contractuelles et l'établissement de relations dans le but de réduire la responsabilité juridique des services d'bygitne du travail en veriu des lois pertinentes. Cependant, il $n$ 'y a pas de fondement juridique $d$ I'imparrition en vertu du Code criminel. II est plus important que jamais de souligner un bon libellé de la convention. les dispositions d'indemnité et les systèmes de gestion de services d'hygiène du travail.

\section{TABLE OF Contents}

1. INTRODUCTION ............................... 160

II. HEalth AND SAFETY IN THE Canadian

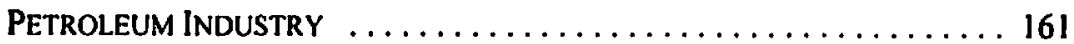

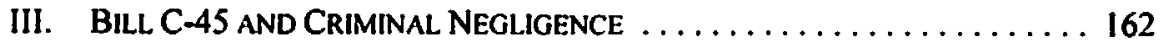

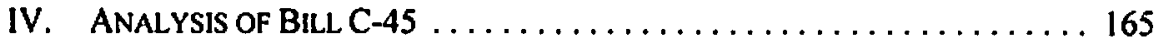

V. UNDERSTANDING CANADIAN OCCUPATIONAI.

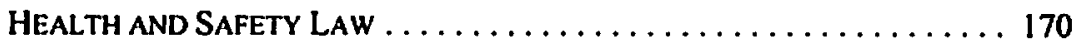

VI. The Alberta OHS PERSPECTIVE $\ldots \ldots \ldots \ldots \ldots \ldots \ldots \ldots \ldots \ldots \ldots \ldots$

VII. Criminal Chaterter Protections ..................... 179

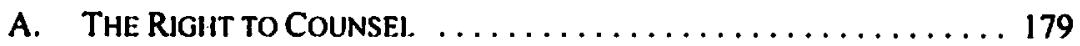




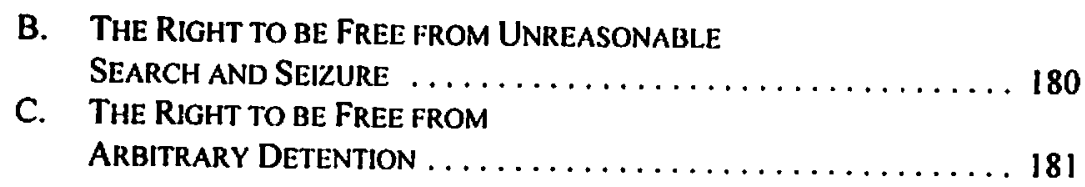

\section{INTRODUCTION}

The purpose of this article is to review Bill C-45' and its implication for the petroleum industry in Canada. Bill C-45 was passed into law on 31 March 2004 and has important implications for occupational health and safety (OHS) law and the criminal liability of individuals and organizations in Canada. Often referred to as the "Westray Bill," Bill C-45 is part of the legal legacy of the 26 workers who died on 9 May 1992 at the Westray mine in Nova Scotia.

Bill C-45 fundamentally adds to, rather than replaces, existing provisions under the Criminal Code of Canada. ${ }^{2}$ Bill C-45 establishes a new OHS duty on everyone who directs how others perform work. It replaces the term "corporation" in the Criminal Code with the new term "organization." The new liability provisions of Bill C-45 for organizations apply to more than just the new OHS criminal negligence offence and dramatically amend the fault elements of all offences against organizations under the Criminal Code.

Criminal law in Canada is a federal legislative responsibility. Canadian criminal law is enacted by Parliament, primarily in the Criminal Code. Criminal law provides the most severe legal censure available in the Canadian legal system. The complexity of Canadian criminal law and the rights of the accused have been increased by the development of the Canadian Charter of Rights and Freedoms. ${ }^{3}$ Most penal offences in Canada are regulatory and not criminal offences. These types of offences may be legislatively enacted by Parliament, provincial legislatures or municipalities. Regulatory offences include highway traffic offences, environmental offences, offences for over-fishing and offences for harmful commercial practices, including misleading advertising and OHS offences.

On 12 June 2003, the day Bill C-45 was introduced in Parliament, the Honourable Martin Cauchon, then Minister of Justice and Attorney General of Canada, said that:

\footnotetext{
Employers must fully recognize tlıcir responsibility in providing a safe work cuvironment. Failure to do so in a manner that endangers employee and public salety must be appropriately dealt with through our criminal laws. I am pleased to introduce measures today that will effectively modernize the law on corporate liability.
}

I An Act to amend the Criminal Code. 2d Sess., 37th Parl., 200I (assenled to 7 November 2003). S.C 2003, c. 2] [Bill C-45].

R.S.C. 1985, c. C-46 [Criminal Code].

Part I of the Constimtion Act. 1982, being Schedule B in the Canada Act 1982 (U.K.), 1982, c. II [Charter] came into effect on I April 1982.

Department of Justice Canada. News Release. "Justice Minister Introduces Measures to Protect Workplace Safety and Modernize Corporate Liability" (12 June 2003), online: Department of Justice Canada <canada.justice.gc.ca/en/news/nr/2003/doc_30922.htmil>. 


\section{Healti and Safety in the Canadian Petroleum Industry}

Health and safety in the Canadian petroleum industry is critical for the effective management of worker risk, worker compensation costs potential, business disruption, corporate and industry reputation, intervention by OHS regulators and OHS prosecutions resulting in investigations, legal costs and serious penalties. Managing health and safety in the petroleum industry is a key industry objective. What follows is a brief summary of some of the statistical information available on the health and safety performance of the Canadian petroleum industry."

The upstream sector of the petroleum industry includes companies that explore for, develop and produce Canada's petroleum resources. Today, the upstream sector includes more than 1,000 exploration and production companies, as well as hundreds of associated businesses, such as seismic and drilling contractors, service rig operators, engineering firms and various scientific, technical, service and supply companies.

Statistics Canada's Standard Industrial Classification - Establishments $1980^{6}$ is a system for classifying establishments according to their primary business activity. It is used to facilitate the collection, tabulation, presentation and analysis of production and related data, including work injuries and diseases. In Canada, work injury and disease statistics are compiled and published by the Association of Workers' Compensation Boards of Canada (AWCBC). ${ }^{7}$ The AWCBC generated work injury and disease statistics for the upstream sector of the petroleum industry by including the following establishments, classified by SIC. E 1980:

D. Mining (including Milling), Quarrying and Oil Well Industries

0710. Crude Petroleum and Natural Gas Industries

071 1. Conventional Crude Oil and Natural Gas Industry

0712. Non-Conventional Crude Oil Industry

E. Manufacturing Industries

3610. Retined Petroleum Products Industries

3611. Refined Petroleum Products Industry (except lubricating oil and grease)

3612. Lubricating Oil and Grease Industry

3690. Other Petroleum and Coal Products Industries

According to the AWCBC, there were a total of 376 accepted injury claims in 2002 in Canada for the above noted industries. Table 1 outlines the number of accepted injury claims by province and industry. Online: Statistics Canada <www. statcan.ca/english/subjects/Standards/sic/sice80-menu. htm> [SIC-E 1980].

- See Association of Workers" Compensation Boards of Canada (AWCBC). "National Work Injuries Statistics Program," online: AWCBC < $4 m$ w.awcbc.org/english/NWISP_Stats.htm>. Data listed below is compiled from this program. 
Table 1: Accepted Injury Claims in Canada by Province and Industry

\begin{tabular}{|l|r|r|r|r|r|r|}
\hline \multirow{2}{*}{ Province } & \multicolumn{4}{|c|}{ Standard Industrial Classification Unit } & \multirow{2}{*}{ Total } \\
\cline { 2 - 6 } & \multicolumn{1}{|c|}{$\mathbf{0 7 1 0}$} & \multicolumn{1}{c|}{3610} & \multicolumn{1}{c|}{3611} & \multicolumn{1}{c|}{3612} & \multicolumn{1}{c|}{3690} & \\
\hline Newfoundland \& Labrador & 2 & - & 11 & - & 2 & 15 \\
\hline Nova Scotia & - & - & 1 & - & - & 1 \\
\hline New Brunswick & - & - & 1 & 2 & - & 3 \\
\hline Quebec & - & - & 21 & 3 & 11 & 35 \\
\hline Ontario & 2 & - & 21 & 15 & 6 & 44 \\
\hline Manitoba & 3 & 4 & - & - & 4 & 11 \\
\hline Saskatchewan & 2 & 9 & 20 & - & 4 & 35 \\
\hline Alberta & 145 & 7 & - & - & - & 152 \\
\hline British Columbia & 7 & - & 72 & - & - & 79 \\
\hline NWT and Nunavut & - & - & 1 & - & - & 1 \\
\hline Tolal & 161 & 20 & 148 & 20 & 27 & 376 \\
\hline
\end{tabular}

The most common injuries among the accepted claims were sprains, strains and tears, followed by fractures and hearing loss or impairment. The most commonly injured body parts were the trunk, including the back, the spine and spinal cord, followed by the inner ear(s) and the lower extremities. The most common events that caused injury were bodily reactions including overexertion, followed by falls, contact with objects and exposure to noise over time.

According to the AWCBC, in 2002 there were a total of 16 fatalities in Canada for the above noted industries. Table 2 outlines the number of fatalities by province and industry.

Table 2: Fatalities in Canada by Province and Industry

\begin{tabular}{|c|c|c|c|c|c|c|}
\hline \multirow[t]{2}{*}{ Province } & \multicolumn{5}{|c|}{ Standard Industrial Classification Unit } & \multirow[t]{2}{*}{ Total } \\
\hline & 0710 & 3610 & 3611 & 3612 & 3690 & \\
\hline Quebec & $\cdot$ & - & 1 & $\cdot$ & $\cdot$ & I \\
\hline Ontario & - & 6 & $\cdot$ & - & 1 & 7 \\
\hline Alberta & 4 & 1 & $\dot{-}$ & - & - & 5 \\
\hline British Columbia & $\cdot$ & $\cdot$ & 3 & - & $\cdot$ & $\mathbf{3}$ \\
\hline Total & 4 & 7 & 4 & - & 1 & 16 \\
\hline
\end{tabular}

The most common source of fatalities in the Canadian petroleum industry was asbestos and the most common cause of death was mesothelioma.

\section{Bill C-45 and Criminal Negligence}

Bill C -45 has established a new legal duty for the health and safety of workers and the public in the Criminal Code. If breached, this duty then gives rise to the new offence of OHS criminal negligence. This new duty works within the existing provisions of the Criminal Code dealing with criminal negligence. Therefore, an introduction to the law of criminal negligence is critical for an understanding of Bill C-45 and its implications. 
Criminal negligence is an offence under the Criminal Code that can arise from either acts or omissions of the accused. If the accused is under a legal duty and breaches that duty by an act or omission, this amounts to the offence of criminal negligence. There are a number of legal duties imposed under the Criminal Code that form part of the basis of the offence of criminal negligence. Some duties imposed under the Criminal Code include: a duty to disperse rioters; ${ }^{\mathrm{B}}$ a duty of care with respect to the handling of explosives; ${ }^{9}$ a duty of care regarding the handling of firearms; ${ }^{10}$ a duty to provide the necessaries of life for a child under the age of sixteen, a spouse or common-law partner and a person under his charge if that person is unable to provide himself with the necessaries of life;" a duty of persons undertaking acts dangerous to life; ${ }^{12}$ a duty to everyone who undertakes to administer surgical or medical treatment to another person; ${ }^{13}$ a duty to safeguard openings in ice and excavations; ${ }^{14}$ and other duties relating to non-Criminal Code duties, such as provincial highway traffic legislation and OHS regulatory duties. However, the mere breach of a duty imposed by a provincial or federal statute, other than the Criminal Code, does not per se constitute criminal negligence. ${ }^{\text {Is }}$

The law of criminal negligence in Canada is found in ss. 219,220 and 22I of the Criminal Code, which provide as follows:

219 (1) Every one is criminally negligent who

(a) in doing anything, or

(b) in omitting to do anything that it is his duty to do. shows wanton or reckless disregard for the lives or safety of other persons.

(2) For the purpose of this section, "duty" means a duly imposed by law.

220 Every person who by criminal negligence causes death to another person is guilty of an indictable offence and liable

(a) where a firearm is used in the commission of the offence. to iniprisonment for life and to a minimum punishment of imprisonment for a term of four years: and

(b) in any other case, to imprisonment for life.

221 Every one who by criminal negligence causes bodily harm to another person is guilty of an indictable offence and liable to imprisonment for a term not exceeding ten years.

The Criminal Code defines the term "bodily harm" as "any hurt or injury to a person that interferes with the health or comfort of the person and that is more than merely transient or trifling in nature."16 The legal interpretation and jurisprudence surrounding the phrase "bodily harm" is quite limited. Justice Borins typified most judicial commentary on the meaning to

lbid. s. 79.

lbid, s. 86.

lbid. s. 215

Ibid., s. 217 .

Ibid., s. 216.

Ibid., s. 263(1)(2).

R. v. Titchner, [1961] O.R. 606 (C.A.).

Supra note 2, s. 2. 
be given to the phrase bodily harm when he said, "bodily harm really requires no explanation, that the words should be given their ordinary meaning, and that the harm need not be really serious." "The Alberta Court of Appeal has stated that bodily harm "includes any hurt or injury which interferes with health or comfort; it need not be permanent but must be more than merely transient or trifling."

Prior to Bill C-45, Canadian courts developed the "identification theory" of corporate criminal liability to hold a corporation responsible for the acts and omissions of senior officers or directing minds of the corporation. An early English case described this level of corporate decision maker as "the directing mind and will of the corporation, the very ego and centre of the personality of the corporation."' Canada goes back to the case of $R$. v. Union Colliery Co. of British Columbia. ${ }^{20}$ This Supreme Court of Canada case from 1900 established that "a corporation can render itself amenable to the criminal law for acts resulting in damage to numbers of people, or which are invasions of the rights or privileges of the public at large, or detrimental to the general well being or interests of the state."21

Since the establishment of corporate criminal liability, the common law has evolved to somewhat broader concept of corporate responsibility. Justice Schroeder in $R$. $v$. St. Lawrence Corp. Ltd. ${ }^{22}$ attributed this trend to the fact that "corporations are at once more powerful and more materially endowed and equipped than are individuals and, if allowed to roam unchecked in the field of industry and commerce, they are potentially more dangerous and can inflict greater harm upon the public than can their weaker competitors."23

A pre-Bill $C-45$ case involving criminal negligence charges in the petroleum industry was the case of $R$. v. Syncrude Canada Lid. ${ }^{24}$ In that case, two men, working for a contractor repairing a large tank, were asphyxiated due to exposure to nitrogen gas after going into a reactor in order to retrieve a fallen tool. Syncrude Canada Lid. had hired an independent contractor, Western Stress Relieving Services Inc. That contractor was hired to carry out repairs to the Syncrude plant near Mildred Lake, Alberta, during a plant shutdown. While servicing a reactor in a confined space a worker dropped a wrench. The worker descended into the reactor to retrieve the wrench and was overcome by toxic fumes. A co-worker, observing the fate of the first worker who was trying to retrieve the wrench, descended into the same reactor to help and was similarly overcome by the toxic fumes. The medical evidence at the trial indicated that both men were likely overcome by nitrogen gas and rendered unconscious in seconds.

The trial judge concluded that it was necessary to look to the alter ego or directing mind of the corporation and that a "clear distinction is made between the acts of inferior agents or

1" R. v. McNamara (1979), 12 C.R. (3d) 210 at 225 (Ont. Co. Ct.).

ix R. v. Martineau (1988), 89 A.R. 162 at para. 40 (C.A.), afrJ [1990] 2 S.C.R. 633.

1." Lemard's Carrying Co. Lid. v. Asialic Petroleum Co. L.d. [1915] A.C. 705 at 713 (11.L.).

(1900), 31 S.C.R. 81.

tbid. at 84 .

[1969] 2 O.R. 305 (C.A.).

Ibid. at 320.

(1983), 48 A.R. 368 (Q.B.) [Syncrude Canada Lid.]. 
servants of the corporation, as opposed to the acts of more responsible officers of the company."2s In that case, the employees who were responsible for the prohibited act were processing technicians who issued safe work permits. Justice Agrees, in dismissing the charges of criminal negligence, stated that:

[He could not] find that in a company with 4,000 employees, permit issuers, albeit they have the authority to implement safety procedures, [could] be considered the directing mind and will of the corporation, the alter ego of the corporation... Their rank and position is not such of a nature as to justify the finding that their acts might be ascribed to the company itself so as to fix the corporation with liability for their acts or omissions. ${ }^{20}$

The "identification theory" of corporate criminal liability was recognized and clearly supported in Canadian law in $R$. v. Canadian Dredge and Dock Co." This criminal prosecution related to alleged bid-rigging in the dredging of the Hamilton harbour. Several charges in the indictments related to contracts between public authorities and the accused where the bids were alleged to have been tendered on a collusive basis, with the low bidders arranging to compensate high bidders or non-bidders in order to secure the contract. Each company had a manager who conducted the business of the company relating to the submission for bids for tender. The corporate accused denied any criminal involvement because the managers were acting fraudulently against their own employers, on their own behalf and contrary to instructions given to them. The identification theory focuses on the actions of the directing mind of the corporation and merges individual and corporate persons in order to assign criminal liability. The Supreme Court of Canada expanded the "directing mind" in Canadian Dredge and Dock Co. to include "the board of directors, the managing director, the superintendent, the manager or anyone else delegated by the board of directors to whom is delegated the governing executive authority of the corporation." ${ }^{28}$ The target group for establishing corporate criminal liability under the identification theory in the common law was previously narrower, including only the board of directors, the managing director and other managers who are highly placed. ${ }^{29}$

\section{ANALYSIS OF BILl. C-45}

Bill C-45 introduces two new tests or formulas by which organizations may be held criminally liable. These two formulas are a departure from the identification theory of corporate liability. The first, s. 22.1 of the Criminal Code, is in respect of offences that require proof of negligence. This section applies to the new OHS legal duty in s. 217.1, which will be reviewed later in this part, as well as other forms of criminal negligence. This provision also recognizes that not all criminal offences have the same fault element. The second, s. 22.2, deals with the new formula for establishing organizational guilt where the fault element is not negligence. In a very real sense, s. 22.1 establishes a statutory fault element that is now the measure of negligence to establish the new offence of OHS criminal negligence, or any other criminal negligence charge.

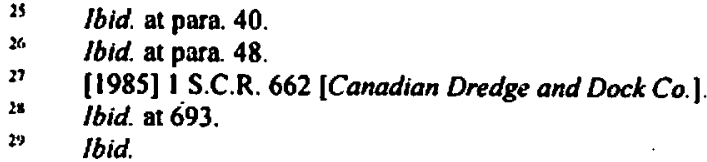


Bill C-45 introduces a duty relating to OHS in the Criminal Code. The duty reads as follows: "Every one who undertakes, or has the authority, to direct how another person does work or performs a task is under a legal duty to take reasonable steps to prevent bodily harm to that person, or any other person, arising from that work or task." ${ }^{30}$ The duty applies to "every one," which includes individuals, the Crown and organizations. Further, the duty applies to everyone who undertakes to direct how another person does work or performs a task. The use of the word "how" clearly modifies and restricts a set of individuals to whom the new legal duty applies. "How" is generally synonymous with the phrase "by what means" or "in what manner or way."

Further, this legal duty also applies to everyone who has the authority to direct how another person does work or performs a task. The phrase, "or has the authority," is problematic since it does not give a particular title or level of responsibility. The new legal duty is to take "reasonable steps" to prevent bodily harm to that person, the person to whom direction is given as to how to do the work or perform the task. The term "reasonable steps" is not defined. Reasonable steps may refer to OHS legislation, industry standards, codes of practice and, in some cases, best practices.

Bill C-45 adds sentencing powers to the courts in the event of a prosecution. One of the fundamental purposes of sentencing is to contribute, along with crime prevention initiatives, to respect for the law and the maintenance of a just, peaceful and safe society. ${ }^{31}$ Bill C-45 does not amend or change any existing sentencing principle in the Criminal Code or in criminal law jurisprudence. However, Bill $\mathrm{C}-45$ establishes a new list of criteria for sentencing organizations in the Criminal Code that must be considered by the sentencing judge. Although many of the principles under the new 5.718 .21 have been previously considered in cases dealing with sentencing principles, they are especially important in view of the new formula for organizational criminal liability.

Under the Bill C-45 amendments to the Criminal Code, ten additional factors are set out that shall be considered by courts when sentencing organizations. Factor (a) is any advantage realized by the organization as a result of the offence. Presumably this would include any money saved by failing to invest in OHS legislative or regulatory compliance that could have prevented the offence from occurring. This may also include specific decisions to forego or delay implementation of safety devices or $\mathrm{OHS}$ training with respect to dangerous equipment, machinery or processes because of the cost involved. Factor (b) requires the court to consider the degree of planning that went into the offence along with the duration and complexity of the offence. Here, a distinction can be made between those offences that are committed with relatively little planning, and those that require careful planning and execution on behalf of the organization. The new offence of OHS criminal negligence does not require proof of planning to result in a conviction. It only requires proof of negligence as set out in 5.219 of the Criminal Code. It remains to be seen if a lack of planning could be an important sentencing consideration for the new offence of OHS criminal negligence. Factor (c) allows the court to consider any attempt taken by an organization to avoid paying a fine or restitution. Converting or concealing assets will not assist an organization to receive a 
reduced fine; in fact, it may lead to an increased penalty. The economic impact of a sentence on the organization, as well as the impact on the employment of employees, is considered under factor (d). In OHS regulatory prosecution cases, however, it has been determined that while this is a valid sentencing factor, it will not be given as much weight as other factors. ${ }^{32}$ Factor (e) makes the cost of prosecution and investigation of the offence a consideration in sentencing. It is not clear if this is limited to police investigation and prosecution or if it may also apply to OHS regulatory investigations and prosecutions.

Factor ( $f$ ) involves any regulatory penalty imposed arising out of events or conduct that also formed the basis of the health and safety criminal negligence offence. Factor (g) looks to previous convictions or regulatory sanctions for similar conduct, either of the organization or one of its representatives, as factors to be considered in sentencing. Evidence that the organization has a history of similar convictions or behaviour will likely result in an increased penalty. This factor is much broader than just looking at a prior criminal record. Factor (h) considers whether the organization has imposed any penalty on a representative for his or her role in an offence. This may be a mitigating factor for the organization when it has recognized the role of a representative in causing the offence and taking steps to prevent a recurrence. However, it may also be an aggravating factor if the organization has unfairly disciplined or discharged a representative as a scapegoat for the organization's crime. Factor (i) requires the court to consider any restitution ordered or amount paid to the victim by the organization. In Fiesta Party Rentals, ${ }^{33}$ the corporate defendant had made a $\$ 20,000$ donation to a charity in the name of the victim of a workplace accident. The court held that although the defendant was not entitled to a dollar for dollar credit for such a charitable donation it was a mitigating factor to be taken into account with all of the other factors. Finally, under factor (j), any measures taken by the organization to reduce the likelihood of committing subsequent offences, can be considered as evidence of how serious the organization is in preventing a recurrence. A genuine display of effort to improve the OHS regulatory compliance by, for example, developing an effective OHS management system and reducing the risk of further incidents will likely be a significant mitigating factor in determining an appropriate sentence.

Bill C -45 adds new optional terms of probation specifically for organizations convicted of criminal offences. There was no predecessor provision in the Criminal Code dealing with special orders of probation for corporations. The result of this addition to the Criminal Code will be a higher level of post-conviction scrutiny of organizations by the courts, probation officers and other regulatory bodies, such as the applicable OHS regulator. This specific authorization for an OHS regulatory body to supervise the development or implementation of OHS policies, standards and procedures set out in these provisions indicates an opportunity for an increased working relationship between the criminal justice system and the OHS regulators in the applicable jurisdiction. This change in the Criminal Code integrates the new OHS legal duty, the new offence of OHS criminal negligence and the new sentencing and probationary powers of the courts, with OHS regulators as regulated by their statutes across Canada.

v R. v. Fiesta Party Rentals (1984) Led., [2000] A.J. No. 1679 at para. 28 (Prov. Ct. (Crim. Div.)) (QI.) [Fiesta Party Rentals]; R. v. Tech-Corrosion Service Lid. (1986), 68 A.R. 161 al paras. 19-20 (Q.B.). 
This new section gives courts special powers with respect to terms of probation just for organizations. These provisions would not apply to an individual who has been convicted of OHS criminal negligence. Probation orders may include making restitution, establishing OHS policies, standards and procedures, communicating those new policies, standards and procedures to its representatives, reporting to ensure the implementation of those policies, standards and procedures, identifying the senior officer who is responsible for compliance of those policies, standards and procedures and reporting to the court on the progress of improved OHS policies, standards and procedures. These are steps that are determined by the court to ensure there are no repeat offences, dangers in the workplace or workplace accidents.

Section 732.1(3.1)(a) of the Criminal Code allows a court to order an organization to make restitution for any loss or damage suffered as a result of the offence. Remoteness of such loss or damage is not addressed, which raises the question of how remote damage must be before this section will not apply. Workers' compensation legislation provides a system to compensate injured workers and their dependents. This subsection raises questions of whether additional compensation may be part of a restitution order.

Paragraph (b) of this new probationary provision of the Criminal Code allows the court to require an organization, after a conviction, to establish policies, standards and procedures to reduce the likelihood of the organization committing a subsequent offence. This probationary power of the courts is similar to current requirements under current OHS statutes and regulations across Canada. The Bill C-45 legal duty requires "reasonable steps" to be taken; ${ }^{34}$ however, if there is such a failure to take those reasonable steps and a conviction results, then the court is now authorized to impose policies, standards and procedures that ought to have been in place to reduce the likelihood of a reoccurrence of the accident, injury or death in the workplace. ${ }^{3 s}$ Criminal courts do not have any previous authority or experience in establishing OHS policies, standards and procedures. The governmental body that does have authority and experience in regulating OHS policies, standards and procedures is the applicable OHS regulator. Therefore, it is very likely that this provision, if invoked as an appropriate probationary order, will be put in the hands of the applicable OHS regulator, rather than the police and probationary officers, for ongoing scrutiny.

Paragraph (c) of this new provision gives the court the authority to order that the OHS policies, standards and procedures that have been required be communicated to its representatives. Communication of OHS policies, standards and procedures is a critical component to an effective OHS management system. Therefore, this probationary order appears to be consistent with the requirement for an improvement in the OHS management system of the organization that has been convicted to ensure that a recurrence of the offence is prevented.

Paragraph (d) of this new provision requires the organization to report to the court on the implementation of those policies, standards and procedures. This heightened accountability. 
for the organization to report its improvements to the OHS management system, complements the new above mentioned probationary orders. Further, it holds the organization accountable to a criminal court for the improvement to its OHS management system by legislating and communicating new OHS policies, standards and procedures. Further, subparagraph (e) of this new provision allows the court to identify a senior officer of the organization who is responsible for compliance with those policies, standards and procedures. This individual, presumably, would be the individual reporting to the court on the implementation of the improved OHS management system.

Paragraph ( $f$ ) of this new provision is novel and may be controversial. It allows a court to compel the organization to provide information to the public regarding the offence with which the organization was convicted, the sentence imposed by the court and any measures that the organization is taking to reduce the likelihood of committing a subsequent offence. In practical terms, this may require an organization to take out an ad in a national newspaper identifying that it has been charged and convicted with the offence of OHS criminal negligence. The organization will also be required to identify the nature of the sentence imposed on the organization and any individual employed by the organization, as the case may be. Further, the organization may also be required to tell the public, in this national advertisement, that it has been compelled by a probationary order to take certain steps to improve its OHS policies, standards and procedures. These types of probationary orders, known as public shaming orders, have become increasingly popular in the United States. Public shaming as a form of punishment has its historical roots in the middle ages in Europe when individuals convicted of crimes were publicly flogged, placed in public stocks and even the subject of very public hangings.

Paragraph (g) of this provision also gives the court a broad power to compel the organization to comply with any other reasonable conditions that the court considers desirable to prevent the organization from committing the offence again or to remedy the harm caused by the offence. This would permit the court to order the organization to comply with OHS statutes and regulations, to provide OHS training to managers, supervisors and workers, and to ensure that an effective OHS management system was in place. These further powers of the court, under the probationary powers of the Criminal Code, are broader than the provisions of any provincial or federal OHS statute. Although OHS statutes and regulations in Canada are increasingly prescriptive with respect to the means by which they require employers to ensure the health and safety of workers, they have generally stopped short of giving courts the extensive probationary powers that are in this new provision of the Criminal Code. A more complete review and understanding of Canadian OHS law is offered in Part $\mathrm{V}$ of this article.

Section 732.1(3.2) gives a court the power to consider the most appropriate regulatory body to supervise the development and implementation of the policies, standards and procedures referred to in the previous paragraph. In other words, a court may reasonably consider the role and authority of the applicable OHS regulator, as established by the applicable OHS statute, to supervise this aspect of the new probationary powers of the court under Bill C-45. This provision clearly indicates the need for a close working relationship between the applicable OHS regulator, the police, the Crown prosecutor and the court in the 
prosecution, sentencing and probationary orders relating to the new offence of OHS criminal negligence.

Penalties for a conviction of the new offence of OHS criminal negligence are severe. An individual is subject to a maximum penalty of ten years in prison if there is injury and life imprisonment if there has been a death. An organization is subject to a monetary fine without a maximum, so the fine could be in the millions of dollars or higher.

\section{Understanding Canadian Occupational. HEALTh AND SafETy LaW}

Canadian OHS law has developed over the last 50 years as a reaction to workplace accidents, injury and death. Canadian workers' compensation legislation predates Canadian OHS law. Since the Merideth Report of $1914,{ }^{36}$ there has been a no-fault system of providing compensation to workers injured on the job. It appears that governments, employers, unions and other workplace stakeholders were more concerned at the beginning of the 20th century with providing workers' compensation protection for injured employees and protecting employers from lawsuits than from preventing accidents in the workplace. ${ }^{37}$ Canadian OHS law developed significantly in the second half of the 20 th century.

Workplace health and safety has no specific jurisdictional designation under the Canadian Constitution Act, $1867 . .^{38}$ The Constitution Act, 1867 sets out a division of powers between the federal and provincial governments. OHS is not the subject of an explicit reference to the division of powers between the federal and provincial governments. Therefore, courts have, from time to time, been called upon to determine whether or not the provincial or the federal government has authority to regulate the workplace by OHS legislation. Approximately 10 percent of Canadian workplaces are federally regulated and 90 percent are provincially regulated for the purposes of labour relations, employment standards, workers' compensation and OHS.

OHS statutes generally set the framework for the health and safety requirements, standards and procedures in the jurisdiction in which they apply. OHS statutes in Canada are based on the internal responsibility system. The internal responsibility system is an overlapping system of rights and responsibility of workplace stakeholders. In addition to the internal responsibility system, Canadian OHS law is also based on the external responsibility system. The external responsibility system is the lawful authority establishing government regulatory accountability.

The external responsibility system has two means of enforcement of OHS requirements, standards and procedures. First is the issuance of orders or directions by inspectors or officers employed by various government regulators. The issuance of an order may be to stop

". Report of the Hon. Sir William Ralph Meredith. C.J.O.. Commissioner for the Legislative Asscmbly of Ontario (Toronto: L.K. Cameron, 1913).

1" For a more complete introduction to the origins of this subject, see Norman A. Keith, Canadian Healh and Safery Law: A Comprehensive Guide to the Statules. Policies and Case Lanv (Aurora: Canada Law Book, 2003) at $1: 10$. 
working immediately or to change a work practice within a reasonable period of time. Second is the laying of charges under OHS laws in Canada as a means of enforcing the duties for various workplace parties. It is an OHS regulatory offence to contravene these duties. This approach to establishing an offence is different than the establishment of a crime under the Criminal Code. Under the Criminal Code certain conduct is expressly designated to be a criminal offence.

Canadian OHS law provides for enforcement, in part, by prosecutions brought as quasicriminal, strict liability offences. There are three types of offences known to Canadian law. The Supreme Court of Canada, in $R$. v. Sault Sre. Marie (City of), ${ }^{39}$ identified the three different categories of offences:

(i) mens rea offences;

(ii) strict liability offences; and

(iii) absolute liability offences.

The enforcement of OHS law against workplace stakeholders that have legal duties has been a growing trend across Canada. The incidence of enforcement of Canadian OHS laws by way of prosecution has increased since the mid-1970s. Workplace stakeholders may include the employer, supervisors, officers, directors, professional engineers, architects, suppliers, workers and others. Although many workplace stakeholders have legal duties under Canadian OHS law, employers are the primary stakeholders that are prosecuted with OHS offences.

The establishment of OHS legal duties on workplace parties, such as Bill C-45, is not new. The common law has long placed a duty on an employer to provide a safe workplace for workers that was free of unnecessary and unreasonable hazards. Canadian OHS law is enforced predominantly by issuing orders and by prosecuting employers. Under Bill C-4S, it is not clear which individuals in the workplace would have the most likelihood of prosecution for breach of the duty. Section 217.1 established a blanket criminal offence, applying equally to all who direct the workplace activities of others. Unlike Canadian OHS law that currently exists, there appears to have been no effort on the part of the drafters of Bill C-45 to clarify the nature or hierarchy of the duty owed. Instead, what Bill C-45 does is effectively state a broad and far-reaching duty, with no corresponding definitions, parameters or guidelines as to how it will apply to various organizational decision makers. If the current OHS prosecutions are any indication of how OHS criminal negligence charges will be laid, then there will likely be a much higher incidence of employers than supervisors and more supervisors charged than workers. Workers sometimes fail to comply, as do supervisors and senior management. However, government OHS regulators appear to focus predominantly on supervisors, senior management and employers in laying charges under applicable OHS legislation. Time will tell if the same will apply to the new offence of OHS criminal negligence.

Enforcement of OHS laws in Canada by way of prosecution may, as in a criminal prosecution, result in a conviction and sentencing hearing. Once an accused is convicted of 
an OHS offence, then the accused is sentenced after submissions from both the Crown prosecutor and the defence lawyer. The following chart sets out the current penalties, including fines and jail terms, for an accused convicted of a Canadian OHS offence.

Table 3: Current Penalties under Canadian OHS Orfences

\begin{tabular}{|c|c|c|}
\hline Jurisdiction & $\begin{array}{c}\text { Maximum Fine for Organization } \\
\text { Accused }^{\text {(11 }}\end{array}$ & $\begin{array}{c}\text { Maximum Fine for Individual } \\
\text { Accused }\end{array}$ \\
\hline Federal" & $\$ 1,000,000$ or two years in jail, or both. & $\$ 1,000,000$ or two years in jail, or both. \\
\hline British Columbia ${ }^{42}$ & $\begin{array}{l}\text { First Conviction } \\
\$ 555,858.32 \text { and an additional } \$ 27,792.93 \\
\text { for each day the offence continues or } 6 \\
\text { months in prison, or hoth. } \\
\text { Subsequent Conviction } \\
\$ 1,111,716.62 \text { and an additional } \\
\$ 55,585.83 \text { for each day the offence } \\
\text { continues or } 12 \text { months in prison, or both. }\end{array}$ & $\begin{array}{l}\text { First Conviction } \\
\$ 555,858.32 \text { and an additional } \$ 27.792 .93 \\
\text { for each day the offence continutes or } 6 \\
\text { months in prison, or both. } \\
\text { Subsequent Conviction } \\
\$ 1,1] 1,716.62 \text { and an additional } \\
\$ 55,585.83 \text { for each day the offence } \\
\text { continues or } 12 \text { months in prison, or both. }\end{array}$ \\
\hline Alberts" & $\begin{array}{l}\text { First Conviction } \\
\$ 500,000 \text { and an additional } \$ 30,000 \text { for } \\
\text { each day the offence continues or } 6 \text { months } \\
\text { in prison, or both. } \\
\text { Subsequent Conviction } \\
\$ 1,000,000 \text {, and an additional } \$ 60,000 \text { for } \\
\text { each day the offence continues or } 12 \\
\text { months in prison, or both. }\end{array}$ & $\begin{array}{l}\text { First Conviction } \\
\$ 500,000 \text { and an additional } \$ 30,000 \text { for } \\
\text { each day the offence continues or } 6 \\
\text { months in prison, or both. } \\
\text { Subsequent Conviction } \\
\$ 1,000,000 \text {, and an additional } \$ 60,000 \text { for } \\
\text { each day the offence continues or } 12 \\
\text { monilis in prison, or both. }\end{array}$ \\
\hline Saskatchewan ${ }^{44}$ & $\$ 300,000$ or two years in prison, or both. & $\$ 300,000$ or two years in prison, or both. \\
\hline Manitobats & $\begin{array}{l}\text { First Conviction } \\
\$ 150,000 \text { and an additional } \$ 25,000 \text { for } \\
\text { each day the offence continues or } 6 \text { months } \\
\text { in prison, or both. } \\
\quad \text { Subsequent Conviction } \\
\$ 300,000 \text { and an additional } \$ 50,000 \text { for } \\
\text { each day the offence continues or } 6 \text { months } \\
\text { in prison, or both. }\end{array}$ & $\begin{array}{l}\text { First Conviction } \\
\$ 150,000 \text { and an additional } \$ 25,000 \text { for } \\
\text { each day the offence continues or } 6 \\
\text { months in prison, or both. } \\
\text { Subsequent Conviction } \\
\$ 300.000 \text { and an additional } \$ 50,000 \text { for } \\
\text { each day the offence continues or } 6 \\
\text { months in prison, or both. }\end{array}$ \\
\hline Ontario $^{\text {th }}$ & $\$ 500,000$ & $\$ 25,000$ or 12 months in prison, or bolh \\
\hline Quebec ${ }^{17}$ & $\begin{array}{l}\text { First Conviction } \\
\$ 20,000 \\
\text { Subsequent Conviction } \\
\$ 50,000\end{array}$ & $\begin{array}{ll} & \text { First Conviction } \\
\$ 1,000 & \text { Subsequent Conviction } \\
\$ 2,000 & \end{array}$ \\
\hline
\end{tabular}

Imerpretation Act, R.S.C. 1985. c 1-21, s. 35(1).

Canada Labour Code, R.S.C. 1985. c. 1.-2, s. 148.

Workers Compensation ACl, R.S.B.C. 1996. c. 492, s. 217

Occupational Health and Safery Act, R.S.A. 2000, c. 0-2, s. 41 [Alberta OHS Act].

Occupational Health and Safety Act, 1993, S.S. 1993, c. O-1.1, s. 58.

Workplace Safety and Health Act, C.C.S.M. c. W210, s. 55.

Occupational Health and Safety ,Act, R.S.O. 1990, c. O.I. s. 66.

An .Act respecting occupational health and safery. R.S.Q., c. S-2.I. s. 237 


\begin{tabular}{|c|c|c|}
\hline Jurisdiction & $\begin{array}{l}\text { Maximum Fine for Organization } \\
\text { Accused }\end{array}$ & $\begin{array}{l}\text { Maximum Fine for Individual } \\
\text { Accused }\end{array}$ \\
\hline New Brunswick ${ }^{48}$ & $\$ 50,000$ or 6 months in jail, or both. & $\$ 50,000$ or 6 months in jail, or both. \\
\hline Nova Scotias" & $\$ 250,000$ or 2 years in prison, or both. & $\begin{array}{l}\$ 250,000 \text { or } 2 \text { years in prison. } \\
\text { or both. }\end{array}$ \\
\hline $\begin{array}{l}\text { Prince Edward } \\
\text { Island }{ }^{\text {si }}\end{array}$ & $\$ 50,000$ or I month in prison, or both. & $\$ 50,000$ or I month in prison, or both. \\
\hline Newfoundland ${ }^{31}$ & $\$ 250,000$ or 12 months in prison, or both. & $\$ 250,000$ or 12 months in prison, or both. \\
\hline Yukon Territories ${ }^{32}$ & $\begin{array}{l}\text { First Conviction } \\
\$ 150,000 \text { or } 12 \text { months in prison, or both. } \\
\text { Subsequent Conviction } \\
\$ 250,000 \text { or } 24 \text { months in prison, or both. }\end{array}$ & $\begin{array}{l}\text { First Conviction } \\
\$ 150,000 \text { or } 12 \text { months in prison, or both. } \\
\text { Subsequent Conviction } \\
\$ 250,000 \text { or } 24 \text { months in prison, or both. }\end{array}$ \\
\hline $\begin{array}{l}\text { Northwest } \\
\text { Territories"st }\end{array}$ & $\$ 500,000$ or 1 year in prison, or both. & $\$ 500,000$ or 1 year in prison, or both. \\
\hline Nunavut Territory & $\$ 500,000$ or I year in prison, or both. & $\$ 500,000$ or 1 year in prison, or both. \\
\hline
\end{tabular}

Due diligence is the primary defence available to an accused against charges under any OHS statute. The second branch requires the accused to prove that it took reasonable steps or precautions to ensure compliance with OHS statutory and regulatory standards. In a criminal prosecution of the new offence of OHS criminal negligence, failure of the accused to take reasonable steps is part of what a prosecutor must prove for this to be a crime.

There is every reason to suggest that if an employer complies with the new duty under s. 217.1 of the Criminal Code, an accused would be compliant with the applicable OHS laws. However, the requirement to take reasonable steps may be difficult to determine consistently across the country since OHS statutes vary jurisdiction by jurisdiction. In most provinces, for example, the OHS legislation contains legal requirements for health and safety committees. In other provinces, specifically Quebec and Alberta, committees are not required unless ordered by regulation or the regulator. These OHS legal requirements may serve as a yardstick in an OHS criminal negligence prosecution to measure whether or not reasonable steps had been taken. However, since there is no national, consistent OHS statute, this makes the interpretation of reasonable steps more problematic. In other words, it is not clear exactly what will amount to reasonable steps under s. 217.1 of the Criminal Code. What is clear is that there will have to be some development of the case law to establish what will constitute reasonable steps to prevent bodily harm to workers and the public. 


\section{The Alberta OHS PERSPective:s}

The Alberta government, and specifically Minister Clint Dunford, the Minister of Human Resources and Employment, has made it a priority to reduce workplace injuries in Alberta by 40 percent by the end of 2004. In an effort to achieve that goal, various pieces of legislation in Alberta have undergone extensive changes and amendments. On 4 December 2002, the maximum penalty for a first offence under the Alberta OHS Act ${ }^{46}$ was increased from a fine of $\$ 150,000$ and/or six months in prison for each charge to $\$ 500,000$ and/or six months imprisonment for each charge. The maximum fine for subsequent offences under the Alberta OHS Act was increased from $\$ 300,000$ to $\$ 1,000,000$.

On 31 March 2003, the new Occupational Health and Safety Regulation ${ }^{57}$ took effect in Alberta. The Regulation deals primarily with administrative and policy issues, but also specifically states that where the legislation requires a worker to perform a safety-related duty, the employer is now explicitly responsible for making sure that the worker performs that duty. ${ }^{58}$ In November 2003, the Alberta Government released the new Occupational Health and Safery Code, ${ }^{39}$ which took effect on 30 April 2004. The Code replaces the existing 11 separate regulations. Some of the changes for oil and gas wells include minimum competency requirements for supervisors of exploration, drilling, servicing, testing and production operations. There are also new requirements for rigging up, ground anchor pulltesting, fluid recovery during darkness and securing pressurized piping.

To date, there have been on average, six to seven OHS prosecutions taking place in Alberta each year. Until recently, administrative limitations on the number of investigators and Crown prosecutors have been the reason for the small number of prosecutions. Now with the government's push to the "Choose Safe, Not Sorry" campaign, the public will likely see the addition of more investigators and more assigned Crown prosecutors to pursue prosecutions in Alberta.

Although work in the oil and gas industry is dangerous at best, the oil and gas industry fatality statistics in Alberta are relatively fair. For the year 2003, the mining and petroleum industry in Alberta had four fatalities, compared to seven in the year 2002. However, from 1 January 2004 until 8 March 2004, the same industry has had three fatalities. In comparison to other industries, such as construction, agriculture and manufacturing, mining and petroleum come in third with agriculture and construction having considerably more fatalities on average. ${ }^{60}$ 
Minister Dunford's 19 January 2004 news release related to the death of a Trican Well Service Ltd. worker back in November 2001. ${ }^{61}$ In that prosecution, Arc Resources Ltd. agreed to enter a plea of guilty to s. 2.1(3) of the Alberta OHS Act. In doing so, it also agreed to make a \$50,000 donation to Alberta Shock Trauma Air Rescue Society (STARS) and was fined $\$ 30,000$ plus a 15 percent victim fine surcharge by a provincial court judge in Stony Plain, Alberta.

Arc Resources Ltd., the prime contractor in this case, had failed to ensure that its workers (Trican Well Service Ltd. workers) were trained in the precautions to take when handling a controlled product. Those "[w]orkers were using compressed air to blow fluids out of coiled, braided steel hose. The hose burst and a fitting failed and struck a worker, fatally injuring him."

In another prosecution that settled before trial in February 2004, Red's Oilfield Service Ltd. was fined $\$ 75,000$ as a result of pleading guilty to failing to ensure the safety of one of its own workers under the $A$ lberta $O H S A C t$. The fine resulted from an explosion at a Crispin Energy Inc. site in northwest Alberta where a worker was killed and another injured. Crispin Energy, the contractor in this case, also received an $\$ 80,000$ fine plus a 15 percent victim fine surcharge in May 2003..$^{3}$

In R. v. Burlington Resources Canada Ltd, ${ }^{64}$ Burlington agreed to pay $\$ 100,000$ to the Job Safety Skills Society, a non-profit society that provides workplace safety training to high school students as part of their curriculum, in addition to a $\$ 5,000$ fine plus a 15 percent victim fine surcharge in exchange for a guilty plea to a charge under the Working Alone provision of the General Safety Regulation ${ }^{65}$ in connection with the death of a contractor employed by Cobra Maintenance Ltd. in March 2002 as a result of hydrogen sulfide gas. Two former Burlington employees were also charged as a result of the incident. They both pleaded guilty to a charge of disturbing the scene of an accident and were fined.

The agreements and contracts in the oil and gas industry between participating parties can include joint ventures, farm in agreements, farm out agreements and operating agreements. Generally these agreements will attempt to place the responsibility of compliance with some or all regulations, including occupational health and safety regulations, and the responsibility for the safe operation of the undertaking with one of the parties to the agreement. Until the passage of Bill $\mathrm{C}-45$, these agreements and contracts were relatively successful in transferring a good portion of the OHS liability to other parties.

Alberta Human Resources and Employment, News Release, "Arc Resources Ltd. to pay $\$ 80,000$ after worker's death" (19 January 2004), online: Albena Human Resources and Employment <www.gov. ab.a/acn/200401/15763.html>.

Alberta Human Resources and Employment, "Completed Prosecutions Under the OISS Act, Regulation and Code: January 1996 to May 5. 2004" at 3, online: Alberta Human Resources and Employment <ivww.3gov.ab.ca/hre/whs/prosecutions/pdI/completed-prosecutions.pdßs. for worker's death" (25 February 2004), online: Alberta Human Resources and Employment <www. gov.ab.ca/acn/200402/15969.html >.

is Alta. Reg. 448/83, s. 14.1, as rep. by Occupational Health and Safery Code Order, Alta. Reg. 321/2003, 5. 2. 
Many of the agreements and contracts that are being used by the oil and gas industry are predicated on what parties within the industry have been able to do up until now while still complying with their duties under the OHS legislation. The present OHS legislation in Alberta indicates that there is to be a prime contractor where there are two or more employers involved in the work at the work site at the same time. ${ }^{66}$ Section 3 of the Alberta OHS ACt states, in part:

(2) The prime contractor for a work sile is

(a) the contractor, employer or other person who enters into an agreement with the owner of the work site to be the prime contractor, or

(b) if no agrecment has been made or if no agreement is in force, the owner of the work site.

(3) If a work site is required to have a prime contractor under subsection (1), the prime contractor shall ensure, as far as is reascnably practicable to do so, that this Act and the regulations are complied with in respect of the work site.

(4) One of the ways in which a prime contractor of a work site may meet the obligation under subsection (3) is for the prime contractor to do everything that is reasonably practicable to establish and maintain a system or process that will ensure compliance with this Act and the regulations in respect of the work site.

In the oil and gas industry there are standard form agreements and contracts that are used industry-wide. Such an agreement is entitled the Canadian Association of Petroleum Land Operating Procedure 1990 (CAPL 1990) which states in part:

303

INDEPENDENT STATUS OF OPERATOR - The Operator is an independent contractor in its operations hereunder. The Operator shall supply or cause to be supplied all material, labour and services necessary for the exploralion, development and operation of the joint lands and ille operation of any production facilities for the joint account. The Operator shall determine the number of employees respecting its operations, their selection, their hours of labour and their compensation. All employees and contractors used in its operations hereunder shall be the employees and contractors of the Opcrator.

PROPER PRACTICES INOPERATIONS - The Operator shall conduct all joint operations diligently, in a good and workmanlike manner, in accordance with good oilfield practice and the Regulations.

401 (iii) (g) The Operator shall, with respect to joint operations, use every reasonable effort to have its contractors and sub-contractors:

(i) comply with Unemployment Insurance, Workers' Compensation and Occupational Health and Safety legislation and all other similar Regulations applicable to workers employed by them: ${ }^{67}$

Supra note 43, s. 3.

6. Canadian Association of Petroleum Landmen (CAPL). CAPL Operasing Procedure (Calgary: CAPL. 1990). 
The CAPL 1990 operating procedure is generally attached to a head agreement requiring the appointment of an operator. That agreement would describe the lands and working interest of the parties and would normally designate an operator. "Operator" is defined in CAPL 1990 as the "party appointed by the Joint-Operators to conduct operations hereunder for the joint account, except as provided in Clause 1004."

Drilling contracts are also relatively standardized in the industry. The operator and the contractor (usually the drilling company) will generally use a standard form contract endorsed by the Canadian Association of Petroleum Producers (CAPP). The CAPP master form of contract sets out the terms by which the contractor provides for the drilling of the wells on the lands. The contractor will provide equipment, materials, supplies, services and labour in order to drill a well, although the parties can agree that some equipment will be furnished by the operator.

Drilling operations are conducted on a "daywork" basis. The contractor, through these contracts, is deemed an independent contractor and no one in the contractor's group is to be considered an employee, agent or representative of the operator.

\section{The CAPP Master Daywork Contract ${ }^{68}$ states in part:}

5.I Contractor agrees to perform its work pursuant to tach Drilling Program with due care and diligence, in a good and workmanlike manner, in accordance with good drilling practices and in accordance with any additional written policies or guidelines that are agreed to by Contractor and Operator and attached to the applicable Program Specification Sheet.

Certain work, including downhole work, is sometimes covered by the Petroleum Services Association of Canada (PSAC) Master Service Agreement, which states in part:

\section{SAFETY}

5.1 The parties to this Agreement shall conduct their respective operations with all due diligence and safety and in accordance with good oilfield practices.

5.2 Owner having superior knowledge of each Work site and the conditions surrounding it, shall provide Supplier with all necessary information to enable it to perform the Work salely and efficiently. Where hazardous or unusual conditions exist. Owner shall notify Supplier in advance and make such special arrangements as are reasonably required to ensure safe working conditions for Supplier, and its subcontractors at the Work site.

5.3 Owner agrees to provide Supplier with Owner's safety rules and regulations governing the Supplier's operations under this Agreement prior to the commencement of the Work. Supplier agrees to observe and abide by all Owner's reasonable safety regulations while Work is being performed. 
5.4 Supplier reserves the right to suspend performance of the Work if, in Supplier's sole opinion, unsafe conditions exist or if actions requested by Owner are deemed to be unsafe."

7. INSURANCE

7.I At any and all times during the effective period of this $\wedge$ greement, Supplier and Owner each agrec to carry insurance of the types and in minimum amounts as follows:

(a) Workers' Compensation insurance in full compliance with all applicable Territory, Provincial and Federal laws and regulations.

(b) Employers Liability insurance, with minimum limits of $\$ 1,000,000$ per occurrence, covering injury or death to any employee which may be outside the scope of the Workers ${ }^{\circ}$ Campensation statute of the Province of Territory in which the Work is performed.

\section{COMPLIANCE WITH LAWS}

Supplier and Owner agree to comply with all laws, rules and regulations, federal, provincial, territorial and municipal, which are now or may become applicable to the Work referred to in this Agreement. ${ }^{69}$

These agreements attempt to clarify and address various issues between the parties to the agreement, including insurance, health and safety and civil liability. Now with Bill C-45, and specifically s. 22.1 of the Criminal Code and the definition of "representative" to include a contractor, establishing an organization's guilt, it is clear that the industry standard agreements will not afford protection against potential criminal charges for organizations. This is the law for two reasons. First, a "representative" includes a contractor for the purpose of establishing organization guilt under Bill C-45. Second, as a party cannot contract out of potential criminal charges and the Criminal Code. Parties to these agreements would be prudent to review not only their own health and safety policies and procedures but also those of the other parties to the agreement. We recommend five steps be taken to reduce the risk of criminal liability:

1) Senior Executive awareness of Bill C-45.

2) Conduct an OHSLAW Gap Analysis ${ }^{\mathrm{TM}}$ to identify OHS legislative gaps to ensure compliance. $^{70}$

3) Establish or review OHS management system.

4) Establish proper OHS program for contractors.

5) Training of Managers and Supervisors in OHS Due Diligence 


\section{ViI. Criminal Charter Protections"}

Bill C-45 increases the scope and application of the criminal liability of organizations and individuals in Canada. Accordingly, the petroleum industry will likely be exposed to criminal investigations and charges where it had no previous experience. Faced with this prospect, it is important to have a basic understanding of the Canadian criminal justice process as well as the fundamental rights the Charter affords to each accused.

The new offence of OHS criminal negligence is a criminal offence and will be prosecuted under the Canadian criminal justice system. Under the Constitution Act, 1867 only Parliament may enact laws concerning criminal law and procedure. ${ }^{22}$ Most criminal law in Canada is contained in the Criminal Code and under the Controlled Drugs and Substances Act. ${ }^{73}$ Not all laws enacted by the federal government, however, are enacted pursuant to its criminal law power. For example, the Canada Labour Code, ${ }^{74}$ regulating occupational health and safety in federally regulated workplaces, is passed pursuant to the federal government's authority to regulate federal works and undertakings, not criminal law. Most OHS laws in Canada are passed under the authority of provincial jurisdiction.

The Criminal Code applies across Canada and sets the standard of what constitutes criminal behaviour in every part of the country. ${ }^{75}$ There is no comparable OHS statute of national application. In this respect, the Criminal Code is consistent in setting standards of criminal behaviour throughout Canada. No person may be convicted or discharged of a Criminal Code offence committed outside of Canada. ${ }^{76}$ The Criminal Code provides for some exceptions for offences on an aircraft, ship, fixed platform or spacecraft that are outside of Canada but that have a designated connection with Canada."

\section{A. THE RIgHT To Counsel.}

As previously referenced above, the criminal investigative activities of the police are restricted by various rights under the common law and under the Charter, including the right to counsel under s. $10(\mathrm{~b})$. Section 10 states that:

Everyone has the right on arrest or detention:

(a) to be informed promptly of the rensons therefor;

(b) to retain and instruct counsel without delay and to be informed of that right.

"Note that the following discussion is intended to help persons criminally charged under the provisions of the Criminal Code that will be amended or added through the enactment of Bill C-45. Also. the areas of procedure described below do not necessarily form part of every case. They provide a general overview of common stages. Fvery criminal proceeding has a life and history of its own and will be influenced by the particular facts of each case and the procedural decisions and options available.

7. Supra note 38. 5. $91(27)$.

"S.C. 1996, c. 19

is Supra note 41.

15 Although the Criminal Code is the pre-eminent source tor determining ofrences in Canada, there are also a number of other federal offences declared in other federal statules and regulations, as well as provincial offences such as driving and liquor oflences declared in provincial statutes and regulations. 
The right to legal counsel is a fundamental right of every suspect or accused. The right to legal counsel has been explained by the Supreme Court of Canada as follows:

[W] hen an individual is detained by state authorities, he or she is put in a position of disadvantage relative to the state. Not only has this person suffered a deprivation of liberty, but also this person may be at risk of incriminating him- or herself. Accordingly, a person who is "detained" within the meaning of s. 10 of the Charter is in immediate need of legal advice in order to protect his or her right against self-incrimination and to assist him or her in regaining his or her liberty. ${ }^{78}$

Once an accused has expressed his or her desire to retain a lawyer, the police cannot question the accused until he or she has had a meaningful opportunity to speak with a lawyer. The same right is afforded to organizations charged with a crime. Through its directors or officers, the organization can consult with a lawyer to ascertain its rights. Nonetheless, once an accused has received advice from his or her lawyer, the police can resume their questioning. Therefore, an accused should remember that at all times he or she is under no obligation to say anything to the police and that by not saying anything, he or she will not be adversely prejudiced at a later point in time. ${ }^{7}$

It is a Charter violation if the police tells an accused that he or she has a right to a lawyer but then proceeds to tell the accused that he or she does not really need a lawyer. ${ }^{80}$ By doing so, a police officer has been held by the courts to be depriving the accused of the right to make a meaningful decision because the police officer is providing advice. Further, if an accused expresses concern about his or her ability to afford a lawyer, the police must inform him or her of the availability of legal aid and/or duty counsel. ${ }^{81}$

\section{B. The RigitT to be. Free from UnReasonable SEarch and SEIzUre}

It is the fundamental right of every Canadian individual and organization to be secure against unreasonable and arbitrary searches by the police and not to have their property seized for use as evidence as a result of such searches. This right, firmly rooted in our common law legal tradition, is now codified as a constitutional right in 5.8 of the Charter. The Supreme Court of Canada has interpreted the purpose of $s .8$ of the Charter to be the protection of people's reasonable expectations of privacy. ${ }^{82}$ The law generally does not oblige any person to engage in self-incrimination. This includes warrantless searches in one's home or place of business, body searches for possible production of DNA evidence ${ }^{83}$ and the acquisition of someone's or a business' hydro information or bank records. The right to be free from unreasonable search and seizure, under s. 8 of the Charter, in the taking of forensic DNA evidence is protected by s. 487.05 of the Criminal Code. That provision permits a

R. v. Bartle, [1994] 3 S.C.R. 173 at 191 [emphasis in original].

Criminal Code, supra note 2, s. 7.

R. v. Burlingham, [1995] 2 S.C.R. 206.

Duty counsel is a government lawyer who is available before court to advise accused persons. It is provided to ensure that an accused person will have the benefit of legal advice and assistance when appearing before the coun unrepresented. All accused persons are entitled to assistance by duty counsel regardless of their financial means. The financial eligibility guidelines governing the issuance of Legal Aid certificates does not apply to the Duty Counsel program.

See Hunter v. Southam Inc., [1984] 2 S.C.R. 145.

See R. v. Stillman, [1997] I S.C.R. 607. 
provincial court judge to issue a DNA warrant for the taking of bodily samples for forensic DNA analysis. A provincial court judge may issue a DNA warrant where there are reasonable grounds to believe that a designated offence has been committed and that a bodily substance has been found or obtained at the scene, on or in the victim, on anything worn or carried by the victim, or on or within the body of any person or anything or at any place associated with the commission of the designated offence. The provincial court judge, in considering a request for a DNA warrant, must consider the nature of the designated offence and the circumstances of its commission and where there is a peace officer or other person with the necessary training who is able to take the bodily sample from the suspect.

Evidence acquired as a result of an illegal search and seizure may be subject to an application for exclusion from being used as evidence at trial if it may affect the fairness of the trial..$^{84}$ However, if the prosecution can show that illegally obtained evidence was to inevitably be found, the evidence may be admissible. The court may be called upon to determine, under s. 24(2) of the Charter, whether the admission of the illegally obtained evidence brings the administration of justice into disrepute. Section $24(2)$ requires that evidence shall be excluded if, having regard to all of the circumstances, the admission of the evidence would bring the administration of justice into disrepute. In addition to remedies under s. 24(2) of the Charter, evidence may also be excluded under s. 24(1) of the Charter. For example, if the admission of evidence undermines an accused's right to a fair trial, pursuant to s. 11(d) of the Charfer, then an order excluding the evidence may be obtained from the trial judge. Evidence may be rendered unfair at trial because the way that it was taken may render it unreliable or its potential for misleading the trier of fact may outweigh any such minimal probative value that it may possess. Further, if the police have acted in such an abusive fashion that the court concludes that the admission of the evidence would irremediably taint the faimess of the trial itself, it may also be excluded under the authority of s. 11(1) of the Charter. ${ }^{85}$

\section{The Right TO Be FREe from ARbitraRy Detention ${ }^{86}$}

A detention occurs when a person has been taken into police custody or believes that he or she does not have the option to leave the police when being detained or questioned. Many people do not know exactly what the authority of the police is and will tend to err on the side of cooperation rather than caution when dealing with them. When confronted by police, even if feeling uncomfortable and pressured, individuals will often decide not to leave or defer questioning. The law clearly states that any person has the right not to be arbitrarily detained by the police. If a person was unlawfully detained by the police, without legal representation, it is possible that any evidence gathered was obtained contrary to s. $10(\mathrm{~b})$ of the Charfer. The corresponding right of a detained person to retain and instruct a lawyer without delay and to be informed of that right is an important pre-charge right of every individual under the Charter. 